\title{
Thermal Treatment of Dredged Sediment in a Rotary Kiln: Investigation of Structural Changes
}

\author{
Jocelyn Ramaroson,* Moussa Dia, Jean-Louis Dirion, and Ange Nzihou \\ Université de Toulouse, Mines Albi, CNRS, Centre RAPSODEE, Campus Jarlard, F-81013, ALBI Cedex 09, France
}

\section{Guy Depelsenaire}

Direction Centrale de la Recherche Technologique SOLVAY SA, rue de Ransbeek 310, B-1120 Bruxelles, Belgique

\begin{abstract}
Sediment deposits cause the silting of channels, rivers, and lakes. This completely natural phenomenon is exacerbated by the introduction of industrial and urban wastes into the erosion and sedimentation process. Other problems then appear, such as an increased risk of flooding, a reduced capacity for biological purification, and an associated loss of biodiversity. The presence of toxic compounds in the sediments (of industrial, household, or agricultural origin) worsens the situation, and measures must be taken to restore the natural environmental conditions and processes. This study assesses the technology of treating heavy metals from dredged sediments using phosphoric acid (the NOVOSOL process, which was developed by SOLVAY), which aims to convert metals, mainly $\mathrm{Pb}, \mathrm{Cd}, \mathrm{Zn}$, and $\mathrm{Cu}$, into insoluble metallic phosphates, and (by calcination) to engineer the properties of the final residues for beneficial use. The effectiveness of this treatment was evaluated by creating the chemical reaction, followed by convective drying and maturation of the treated sediment at ambient temperature, and finally by calcination $\left(400-1000{ }^{\circ} \mathrm{C}\right)$. This paper focuses on the study of the decomposition of organics and structural change in the sediment during thermal treatment in a rotary kiln. The results showed that the specific surface, the particle size, and the total organic of the sediment are dependent on the calcination parameters such as the residence time, the calcination temperature, and the flow rate. The degradation of the organic compounds is effective at $600{ }^{\circ} \mathrm{C}$. An increase in specific surface is observed until $600{ }^{\circ} \mathrm{C}$, followed by a significant reduction accompanied by a densification and growth of particles. This increase in specific surface area observed attributed to the formation of pores due mainly to the decomposition of organics and the gas evolve $\left(\mathrm{CO}_{2}\right.$, $\left.\mathrm{H}_{2} \mathrm{O}, \ldots\right)$ from $600{ }^{\circ} \mathrm{C}$ to $900{ }^{\circ} \mathrm{C}$.
\end{abstract}

\section{INTRODUCTION}

Over the last century, a degradation of our harbors has resulted from extensive contamination of the associated sediments. The maintenance of waterways is of great concern in the United States as well as in European countries, since there currently is no satisfactory solution to the management of dredged sediments. The case of sediments is of particular interest, since large amounts of sediments are dredged to maintain harbor installations and keep rivers navigitable. When the dredged zone is located near industrial, urban, or specialized sites, these sediments are, in most cases, polluted by heavy metals and organic compounds, such as polyaromatic hydrocarbons $(\mathrm{PAHs})^{1-3}$ and dioxins, ${ }^{4}$ that are harmful to the environment and may also, at high concentrations, be a threat to human health. Depending on their metal contents and degree of toxicity, dredged sediments will be spread on agricultural land, confined, or sent for chemical treatment. ${ }^{5}$ In many cases, simply spreading them on land is no longer possible, for obvious safety reasons.

Consequently, the dredging of this material for channel maintenance and expansion presents a potentially enormous cost generated by its removal, treatment, and ultimate disposal. Therefore, stabilizing metal pollutants and destroying organics from these sediments, for either beneficial reuse or safe storage, is a very attractive option. There is growing interest in new processes than can stabilize trace metals and destroy organic pollutants in these sediments, thus allowing them to be used for the production of secondary materials. One technology to accomplish this objective is the treatment of raw dredged sediments with soluble phosphates followed by calcinations. The treated product has potential uses in roadway pavements, concrete, and brick manufacture, as well as other potential applications. SOLVAY has developed such a technology (the NOVOSOL process) ${ }^{6}$ to immobilize metal contaminants into hydroxyapatite $\left(\mathrm{M}_{5}\left(\mathrm{PO}_{4}\right)_{3} \mathrm{OH}\right.$, where $\mathrm{M}=\mathrm{Ca}^{2+}$ or other divalent metals) and decompose organic pollutants. This treatment process has been optimized for fly ashes, automobile shredder residues, and dredged sediments contaminated with both inorganic and organic pollutants.

Incorporation of wastes into construction materials is a new field that is growing in many countries. Recent studies demonstrate the potential utilization of the treated sediments as a base for the fabrication of construction materials, the rehabilitation of quarries, the building of waterway banks and paths, and the fabrication of bricks. These studies also demonstrate the eco-compatibility of the end product in its 
final application. Experimental projects dealing with these issues are in progress in France, Italy, and Belgium.

The current practice used for the management of contaminated dredged sediments is to store them in controlled watertight lagoons, but this practice is becoming more restricted, because of the negative effects on landscape and an increase in odor emissions, and also because the practice does not address the risk the polluted sediments pose in the long term. Plants growing on the stored deposits have been tested for their potential to take up the pollutants, but bioremediation takes years and only represents a pollution transfer. ${ }^{7}$

The aim of the Novosol technology is to immobilize heavy metals in sediments as a stable, insoluble, nonvolatile metalphosphate complex and then, if necessary, calcine the sediments, to destroy toxic organics and produce usable materials with valuable physical properties (density, surface area, particle size). The process consists of three successive stages: chemical treatment with phosphoric acid (3 wt \%), drying and maturation at room temperature, and a thermal treatment between 400 and $900{ }^{\circ} \mathrm{C}$. The first stage is a liquidsolid reaction during which the sediment is brought into contact with a liquid reagent (phosphate). The objective of this step is to immobilize the heavy metals $(\mathrm{Pb}, \mathrm{Zn}, \mathrm{Cu}, \mathrm{Co})$ and metalloids (As) in the form of insoluble metal phosphate precursors. These created phosphates are insoluble in a large range of $\mathrm{pH}(7<\mathrm{pH}<10)$ values, and this represents a significant improvement when compared to other metal hydroxide or salt forms. The resulting chemical transformation creates new phosphate compounds in which the heavy metals are trapped, as described in the simplified example below:

$$
\begin{aligned}
& 10 \mathrm{~Pb}^{2+}+6 \mathrm{H}_{2} \mathrm{PO}_{4}^{-}+2 \mathrm{H}_{2} \mathrm{O} \\
& \stackrel{\text { precipitation }}{\longrightarrow} \mathrm{Pb}_{10}\left(\mathrm{PO}_{4}\right)_{6}(\mathrm{OH})_{2}+14 \mathrm{H}^{+}
\end{aligned}
$$

The second stage, which involves the drying and maturation of the sediment under ambient conditions of temperature and moisture, causes a decrease in the level of moisture. This is explained by progressive evaporation of the moisture (caused by gas emission) and the maturation of the reaction products by continued neutralization of the phosphoric acid thus extending the stability of the final residues and structural changes.

The third stage (which is optional, depending on the final use of the sediments and the presence of organic pollutants) is a calcination of the treated sediments at a temperature high enough to transform the metal phosphate precursors into still more inert crystalline compounds such as hydroxypyromorphite, $\mathrm{Pb}_{5}\left(\mathrm{PO}_{4}\right)_{3} \mathrm{OH}$ or morelandite, ( $\mathrm{Ba}, \mathrm{Ca}, \mathrm{P}-$ b) ${ }_{5}\left(\mathrm{AsO}_{4}, \mathrm{PO}_{4}\right)_{3} \mathrm{Cl}$. In addition, organic matter is eliminated by combustion during this step and the final product is purely mineral in composition.

The latter stage is effectively a sintering process, in that it leads to a reduction in porosity, a decrease in specific surface area, and a growth in particle size. This consequently reduces the environmental availability of the entrapped pollutants, as confirmed by leaching tests performed when assessing environmental impact. ${ }^{8}$

This paper focuses on the study of the change in the physical properties of the sediment during calcination in a pilot rotary kiln. The structural change during thermal treatment was investigated by analyzing particle size, specific surface area, and degradation of organic compounds. A better understanding of the mechanisms behind the changes in these properties will assist in the beneficial reuse of the treated sediment in various industries related to civil engineering. Environmental tests were conducted to prove the stabilization of heavy metals after the calcination in a rotary kiln.

\section{MATERIALS AND METHODS}

Preparation of Sample. The experiments were conducted with sediments from two different regions, named sediment SV and SD. Sediments of Dampremy (SD) and Vraimont (SV) come to the channel axis Brussels-Charleroi in Charleroi region in Belgium. The samples used for calcination were treated with phosphates in the NOVOSOL pilot unit located at Dombaslessur-Meurthe (France). These sediments were chosen because of the industrial history of both regions. After being collected, the sediments were stored in closed plastic containers at $4{ }^{\circ} \mathrm{C}$ to reduce bacterial activity, which could change their physical and chemical properties. In order to determine their characteristics, the French standard AFNOR NF X 31-101 method was used. ${ }^{9}$ It consists in drying the sediment at $40{ }^{\circ} \mathrm{C}$ until total evaporation of the water content and stabilization of its mass, followed by grinding and sieving at $1 \mathrm{~cm}$.

The Pilot Rotary Kiln. Technical Description of the Pilot. Calcinations of sediments were carried out in a pilot rotary kiln.

The pilot rotary kiln consists in a rotating cylinder and a thermal oxidizer to burn the released gases. The rotating drum is $4 \mathrm{~m}$ in length and $0.2 \mathrm{~m}$ in diameter. The cylinder can be tilted from $0^{\circ}$ to $7^{\circ}$. The rotation of the cylinder is driven by an electric motor whose speed can reach up to $21 \mathrm{rpm}$. The treated product is stored in a metal pot. The fume leaving the rotary kiln is conveyed to a thermal oxidizer (post-combustion) to destroy the organic matter that it contains. The smoke must be purged and its temperature lowered. The gas is extracted by a fan and vented out of the chimney.

The furnace, which is presented in Figure 1, is composed of five independent heating zones along the $4 \mathrm{~m}$ length, and is heated electrically up to $1000{ }^{\circ} \mathrm{C}$.

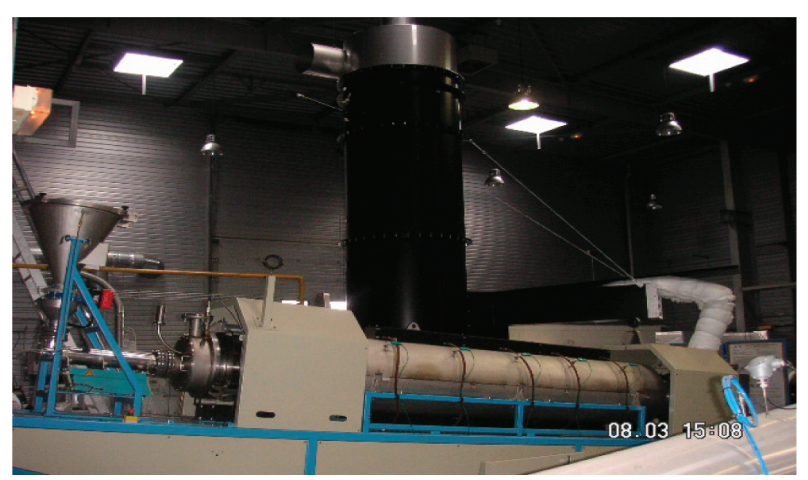

Figure 1. The pilot rotary kiln.

Preliminary Tests before Calcination. Before the calcination experiments, cold tests were performed to investigate the behavior of the solid as it flowed through the furnace. This preliminary step was necessary to check the flow of solid in the cylinder and thus determine the flow regime. The objective was to operate within a "rolling" regime as shown in the Mellmann diagram ${ }^{10}$ presented in Figure 2.

After several tests, the operating parameters to obtain a "cascading-rolling"-type moving-bed flow for dry sediment were: 


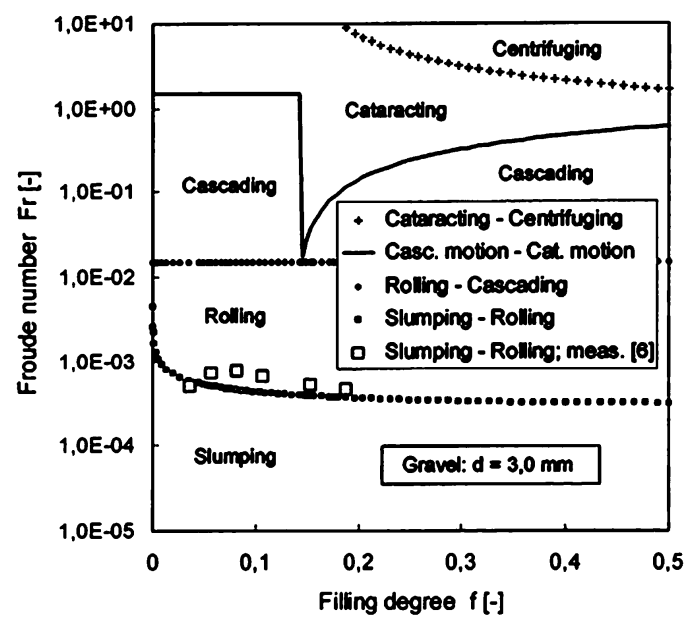

Figure 2. Mellmann diagram.

- Loading rate: between $50 \%$ and $60 \%(3-6.5 \mathrm{~kg} / \mathrm{h})$

- Angle of inclination: $1.1^{\circ}$

- Rotational speed: $2 \mathrm{rpm}$

The height of the bed of solid was estimated at $6 \mathrm{~cm}$ at the entrance of the cylinder.

A diaphragm was installed at the entrance of the cylinder to avoid spillage of solids and, more importantly, to keep the entire height of the bed moving.

The Calcination Procedure. Two main calcinations parameters were studied: the temperature and the residence time of the solids. Their influence on the physical properties of calcined sediments was investigated. In the first experiments, the calcination temperature was changed while the residence time remained fixed. To achieve this, the operating parameters, such as the speed of loading, the angle of inclination, the flow of purge air, and the speed of rotation of the cylinder were kept constant. The calcined sediments were collected (every hour after loading four samples per test) and then analyzed.

The rotary kiln was heated at three different temperatures: 600, 700, and $800{ }^{\circ} \mathrm{C}$.

The calcination conditions are given in Table 1 .

Table 1. Setting of Calcination (Where the Temperature Is Changed)

\begin{tabular}{ccccc}
$\begin{array}{c}\text { temperature } \\
\left({ }^{\circ} \mathrm{C}\right)\end{array}$ & $\begin{array}{c}\text { speed of } \\
\text { loading } \\
(\mathrm{rpm})\end{array}$ & $\begin{array}{c}\text { loading } \\
\text { rate }(\mathrm{kg} \\
\left.\mathrm{h}^{-1}\right)\end{array}$ & $\begin{array}{c}\text { airflow } \\
\text { scanning }\left(\mathrm{m}^{3}\right. \\
\left.\mathrm{h}^{-1}\right)\end{array}$ & $\begin{array}{c}\text { angle of } \\
\text { inclination } \\
(\mathrm{deg})\end{array}$ \\
\hline $600,700,800$ & 2 & 10 & 10 & 1.1 \\
\hline
\end{tabular}

To estimate a theoretical residence time $\tau$, a relationship devised by Sullivan et al. was used: ${ }^{11}$

$$
\tau=\frac{1.77 L(\beta)^{0.5}}{2 R n \theta}
$$

where $\beta$ is the dynamic angle of repose of the "rolling"-bed regime, estimated at $35^{\circ}$.

Next, we studied three different residence times $(167,83$, and $55 \mathrm{~min}$ ), each related to three loading speeds $(1,2$, and 3 $\mathrm{rpm})$, and the rotary kiln was heated at three different temperatures (between $700{ }^{\circ} \mathrm{C}$ and $800{ }^{\circ} \mathrm{C}$ ).

The calcination conditions are grouped in Table 2.
Table 2. Setting of Calcination (Where the Residence Time Is Changed)

\begin{tabular}{cccccc}
$\begin{array}{c}\text { residence } \\
\text { time }(\mathrm{min})\end{array}$ & $\begin{array}{c}\text { temperature } \\
\left({ }^{\circ} \mathrm{C}\right)\end{array}$ & $\begin{array}{c}\text { speed of } \\
\text { loading } \\
(\mathrm{rpm})\end{array}$ & $\begin{array}{c}\text { loading } \\
\text { rate } \\
\left(\mathrm{kg} \mathrm{h}^{-1}\right)\end{array}$ & $\begin{array}{c}\text { airflow } \\
\text { scanning } \\
\left(\mathrm{m}^{3} \mathrm{~h}^{-1}\right)\end{array}$ & $\begin{array}{c}\text { angle of } \\
\text { inclination } \\
(\mathrm{deg})\end{array}$ \\
\hline $167,83,55$ & $700-800$ & $1,2,3$ & 10 & 10 & 1.1 \\
\hline
\end{tabular}

Chemical Characterization. The moisture, heavy metal, and organic contents of the two sediments are presented in Tables $3 \mathrm{a}$ and $3 \mathrm{~b}$. The moisture was determined by drying the

Table 3. (a) Initial Chemical Characteristics and (b) Calcium, Phosphorus, and Metals Contents of the Sediments

\begin{tabular}{lcl}
\multicolumn{4}{c}{ sediment SV } & sediment SD \\
& (a) Initial Chemical Characteristics \\
$\%$ moisture & $34.4 \%$ & $34.4 \%$ \\
$\mathrm{pH}$ & 5.7 & 5.9 \\
$\% \mathrm{C}_{\text {Total }}$ & $4.5 \%$ & $17.5 \%$ \\
$\% \mathrm{C}_{\text {Org }}$ & $3 \%$ & $11.7 \%$ \\
$\% \mathrm{C}_{\text {Inorg }}$ & $1.5 \%$ & $5.8 \%$ \\
& (b) Calcium, Phosphorus, and Metals Contents \\
& $9269 \mathrm{mg} \mathrm{kg}^{-1}$ & $4539 \mathrm{mg} \mathrm{kg}^{-1}$ \\
$\mathrm{P}$ & $14584 \mathrm{mg} \mathrm{kg}^{-1}$ & $52987 \mathrm{mg} \mathrm{kg}^{-1}$ \\
$\mathrm{Ca}$ & $189 \mathrm{mg} \mathrm{kg}^{-1}$ & $278 \mathrm{mg} \mathrm{kg}^{-1}$ \\
$\mathrm{As}$ & $15 \mathrm{mg} \mathrm{kg}^{-1}$ & $38 \mathrm{mg} \mathrm{kg}^{-1}$ \\
$\mathrm{Cd}$ & $823 \mathrm{mg} \mathrm{kg}^{-1}$ & $1143 \mathrm{mg} \mathrm{kg}^{-1}$ \\
$\mathrm{~Pb}$ & $2532 \mathrm{mg} \mathrm{kg}^{-1}$ & $5438 \mathrm{mg} \mathrm{kg}^{-1}$ \\
$\mathrm{Zn}$ &
\end{tabular}

samples at $105{ }^{\circ} \mathrm{C}$ for 3 days. The metal concentration was determined according to the total digestion, as proposed in the NFX 31151 French standard, ${ }^{9}$ followed by dissolution of the solid with $100 \mathrm{~mL}$ of distilled water and analysis by ICP-AES.

After removing calcium carbonate with $\mathrm{HCl}$ in a Thermo NA 2001 CHNS analyzer, the total organic-matter rate was determined using the French Standard NF X31-409. ${ }^{9}$ The chemical characteristics obtained are presented in Tables $3 \mathrm{a}$ and $3 \mathrm{~b}$.

As can be seen from these tables, the two sediments under consideration have very different contents, with regard to carbon and metals.

Physical Characterization. The specific surface area of the samples was determined using nitrogen adsorption by the BET method (Micrometrics, Model Gemini Vacprep 061). The particle-size distribution was determined using a MasterSizer 2000-HYDRO 2000 analyzer from Malvern Instruments. X-ray diffraction (XRD) measurements were carried out with $\mathrm{Cu} \mathrm{K} \alpha$ radiation generated at $40 \mathrm{~mA}$, in the $3^{\circ}<2 \theta<60^{\circ}$ range and at a scanning speed of $2 \%$ min. The phases present were determined by comparing the patterns with JCPDS standards. The surface characteristics of the sediments (microstructure) were studied using environmental scanning electron microscopy (ESEM) (Model XL 30 ESEM-FEG, Phillips). The XRD diffractograms for the two sediments are presented in Figure 3.

The results obtained by XRD measurements showed that the sediments were mainly composed of silica, clay, feldspar, and calcite.

The initial physical characteristics (density, size distribution, and specific surface area) of the two sediments are presented in Table 4.

Environmental Test Procedures. The objective is to assess the stabilization of heavy metals in the solid phase. For 


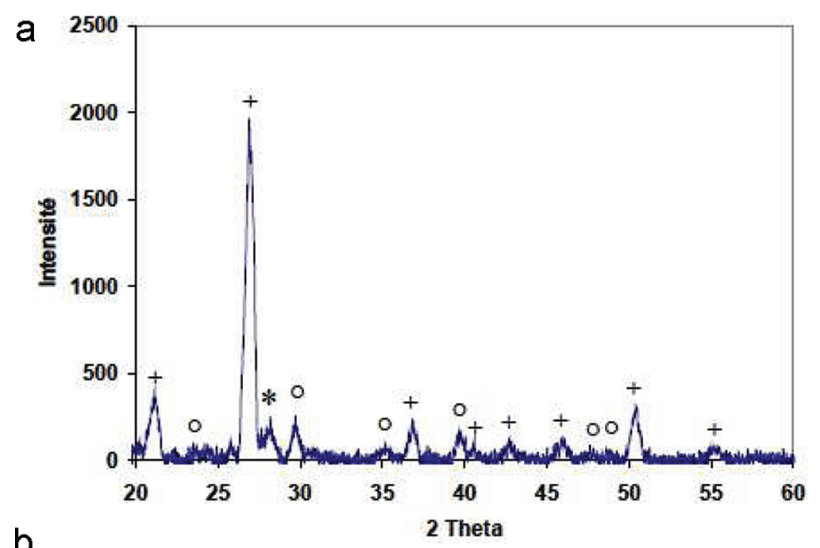

b

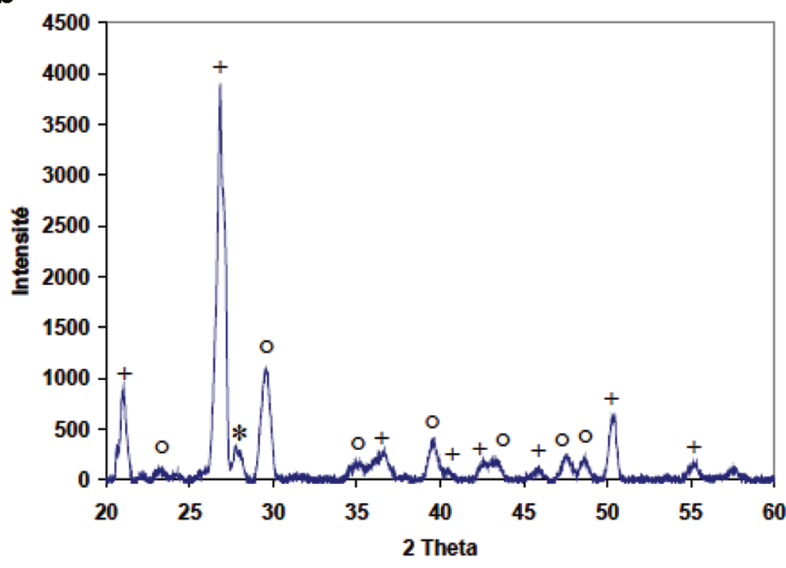

Figure 3. XRD diffractograms of (a) sediment SV and (b) sediment SD. (Legend: $(+)$ quartz, $(\bigcirc)$ calcite, and (*) feldspar.)

Table 4. Characteristics of the Sediments

\begin{tabular}{rccc} 
sample & $\begin{array}{c}\text { density } \\
\left(\mathrm{kg} \mathrm{m}^{-3}\right)\end{array}$ & $\begin{array}{c}\text { size distribution, } \\
D_{50}(\mu \mathrm{m})\end{array}$ & $\begin{array}{c}\text { specific surface area, } S_{\mathrm{SA}} \\
\left(\mathrm{m}^{2} \mathrm{~g}^{-1}\right)\end{array}$ \\
$\begin{array}{c}\text { sediment } \\
\text { SV }\end{array}$ & 2.45 & 28.0 & 10.1 \\
$\begin{array}{c}\text { sediment } \\
\text { SD }\end{array}$ & 2.45 & 28.6 & 10.6 \\
\hline
\end{tabular}

this, TCLP (Toxicity Characteristic Leaching Procedure) methods were used. TCLP Method 1311, as described in the United States Environmental Protection Agency Publication SW-846 (USEPA, 1998) is used as the test method for assessing the environmental behavior. ${ }^{12}$ In this work, it was used to determine the mobility of various heavy metals present in the sediments. The majority of leaching tests use demineralized water as the extraction liquid but the TCLP uses acids. The objective of this environmental characterization is to estimate the release of sediments in hard environmental conditions, similar to a material subjected to acid rain. The extraction liquid is dependent on the alkalinity of matrix studied. The $\mathrm{pH}$ of the samples to be tested is determined in accordance with the TCLP $\mathrm{pH}$ pretest (with $\mathrm{HCl}$ ). Then, $5 \mathrm{~g}$ of sample are transferred to a $500-\mathrm{mL}$ beaker. And then $95 \mathrm{~mL}$ of demineralized water are added. The entire mixture is stirred for 5 min with a magnetic stirrer. The $\mathrm{pH}$ is measured, and if $\mathrm{pH}$ $<5$, extraction fluid \#1 is used. Otherwise, $3.5 \mathrm{~mL} 1 \mathrm{~N}$ hydrochloric acid $(\mathrm{HCl})$ must be added and heated at $50{ }^{\circ} \mathrm{C}$ for $10 \mathrm{~min}$. The $\mathrm{pH}$ value is again determined. If $\mathrm{pH}<5$, extraction fluid \#1 is used; otherwise, extraction fluid \#2 must be used. Extraction fluid \#1 is composed of $5 \mathrm{~mL}$ of glacial acetic acid $\left(\mathrm{CH}_{3} \mathrm{CH}_{2} \mathrm{COOH}\right)$ and of $64.3 \mathrm{~mL}$ of $1 \mathrm{~N}$ soda $(\mathrm{NaOH})$, supplemented with $1 \mathrm{~L}$ of demineralized water. The $\mathrm{pH}$ of this fluid will be $4.93 \pm 0.05$ when it is correctly prepared. Extraction fluid \#2 is composed of glacial acetic acid supplemented with $1 \mathrm{~L}$ of demineralized water. The solution $\mathrm{pH}$ must be $2.88 \pm 0.05$. The fluid extraction employed in this study was fluid $\# 2\left(\mathrm{CH}_{3} \mathrm{CH}_{2} \mathrm{COOH} \mathrm{pH}=2.88 \pm 0.05\right)$. The sediments were extracted for $18 \mathrm{~h} \pm 2 \mathrm{~h}$ with an amount of extraction liquid equal to 20 times the weight of the solid phase. Following the extraction, the liquid extract was separated from the solid phase by filtration (diameter $<45 \mu \mathrm{m}$ ) and analyzed by ICP-AES.

\section{RESULTS AND DISCUSSION}

Influence of the Temperature. Structural Changes. The analysis of the total carbon during the calcination was studied to evaluate the decomposition of organic compounds. The changes in total carbon for sediment SV and SD calcined at different temperatures are presented in Figure 4.

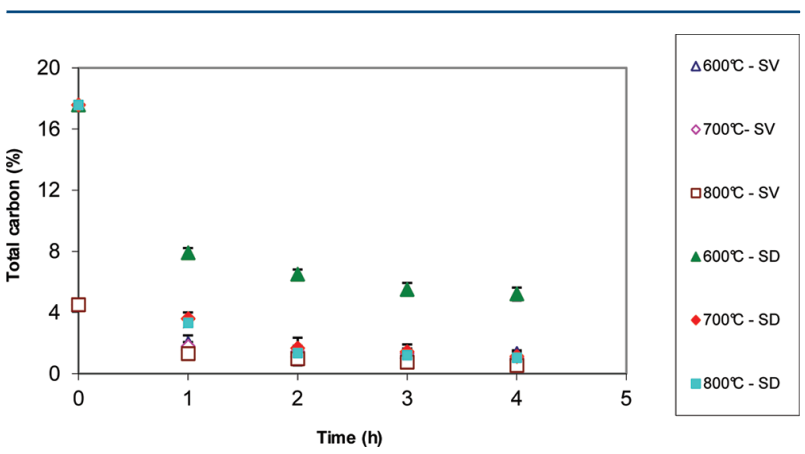

Figure 4. Total carbon during calcination.

It is observed that the total carbon content of sediments decreases with time. This decrease is much stronger in the case of sediment $\mathrm{SD}$, because of its high initial concentration of organic matter. At $600{ }^{\circ} \mathrm{C}$, in the case of sediment SD, the rate of residual carbon is, on average, more than $5 \%$. Calcination at 700 and $800{ }^{\circ} \mathrm{C}$ for this sediment achieves the destruction of almost all organic compounds, as residual rates do not exceed $1 \%$. It can be argued that, for both sediments, the destruction of organic compounds is total from $700{ }^{\circ} \mathrm{C}$.

The changes in specific surface area for sediments SV and SD are presented in Figure 5.

Between 500 and $600{ }^{\circ} \mathrm{C}$, the specific surface area increases for sediment $\mathrm{SD}$. This trend could be explained by the decomposition of organics resulting from the evaporation of $\mathrm{CO}_{2}$ and water vapor generating the creation of porosity in the sediment.

The consequence of such a phenomenon is a significant increase in the specific surface area. For both sediments SD and SV, we note that the specific surface area decreases when the calcination temperature increases. The reduction in surface area observed beyond $600{ }^{\circ} \mathrm{C}$ for both sediments is due to the reduction in porosity and grain growth of the mineral matrix. This phenomenon is confirmed by the ESEM images made at $700-800{ }^{\circ} \mathrm{C}$ presented in Figure 6, and by particle-size analysis using a laser granulometer. This is the phenomenon known as sintering. ${ }^{13,14}$ This process results in the formation of grain boundaries between particles, which leads to a significant 


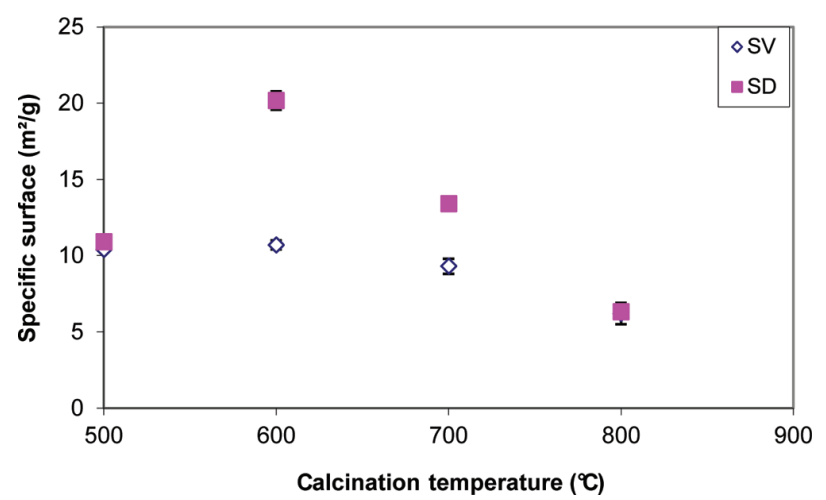

Figure 5. Specific surface area versus calcination temperature.

increase in size and densification, leading to a reduced surface. $^{15,16}$

Changes in particle size during calcination are shown in Figure 7.

Influence of Residence Time. Structural Changes. To study the influence of residence time, three stirring speeds were set.

Changes in total carbon at 700 and $800{ }^{\circ} \mathrm{C}$ for different residence times are presented in Figure 8. In the experimental conditions studied ( 700 and $800{ }^{\circ} \mathrm{C}$ ), the amount of organic matter eliminated is the same, regardless of the time. These results show that the time required for the total elimination of organic matter is $<55$ min.

We note that at 700 and $800{ }^{\circ} \mathrm{C}$, the specific surface area decreased as the residence time increased. This trend is stronger at $800{ }^{\circ} \mathrm{C}$, because of the sintering process, as explained in section 3.1 and confirmed by the results obtained by ESEM and particle-size analysis. Figure 9 shows a particularly sharp increase in the average diameter of the particles.

With regard to the specific surface area, the influence of the temperature is very significant. In fact, at $700{ }^{\circ} \mathrm{C}$, high values of specific surface area (pores created by the degradation of organic matter) are measured, while at $800{ }^{\circ} \mathrm{C}$, where sintering

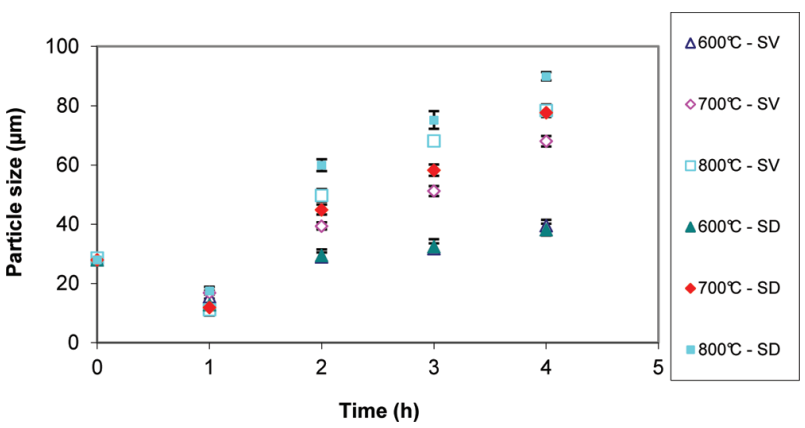

Figure 7. Particle size growth with calcination temperatures.

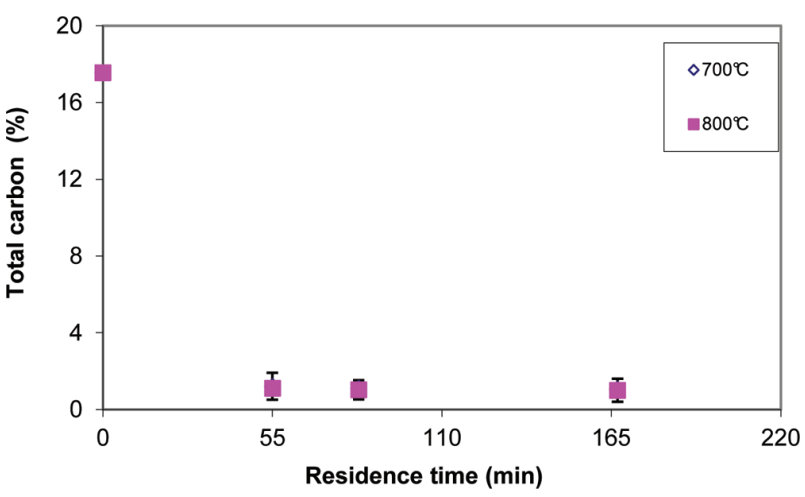

Figure 8. Total carbon rate versus residence time during calcination.

is observed, the surface area reduction is much greater. (See Figure 10.)

Leaching Test Results: Effect of Thermal Treatment. The results obtained after analysis with inductively coupled plasma-atomic emission spectroscopy (ICP-AES) are shown in Table 5a for sediment SV and in Table $5 b$ for sediment SD.

Before calcination, TCLP tests show the presence of some heavy metals above the acceptable limit for sediments SV and $\mathrm{SD}$. After the phosphating process, we note that the acceptance limits are not exceeded. The results of these leaching tests
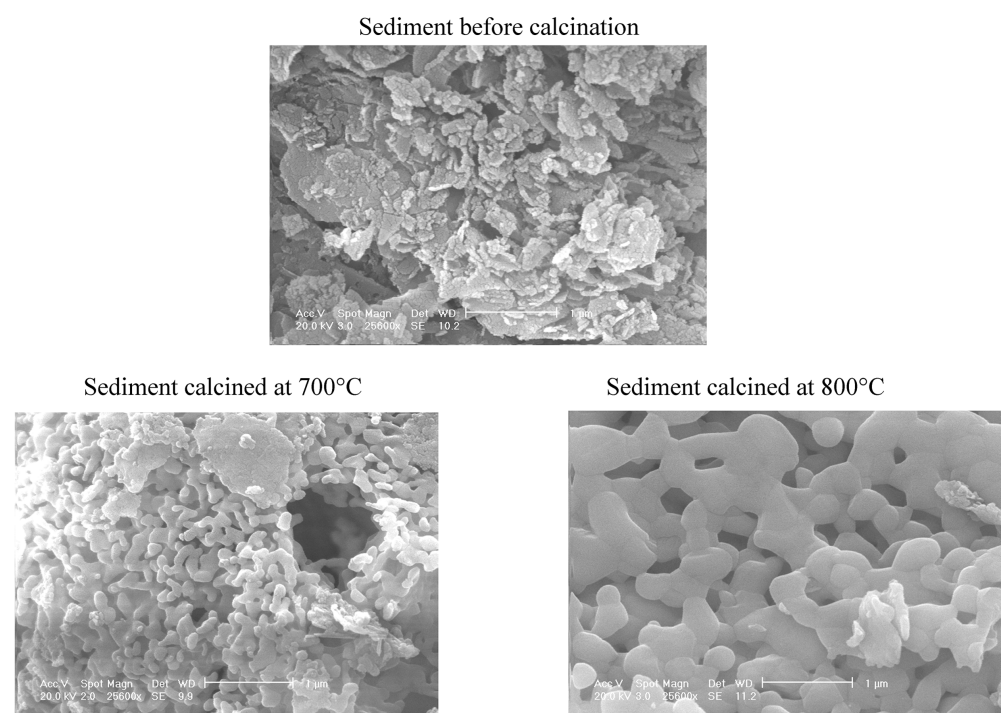

Figure 6. Structural changes by MEBE figures. 


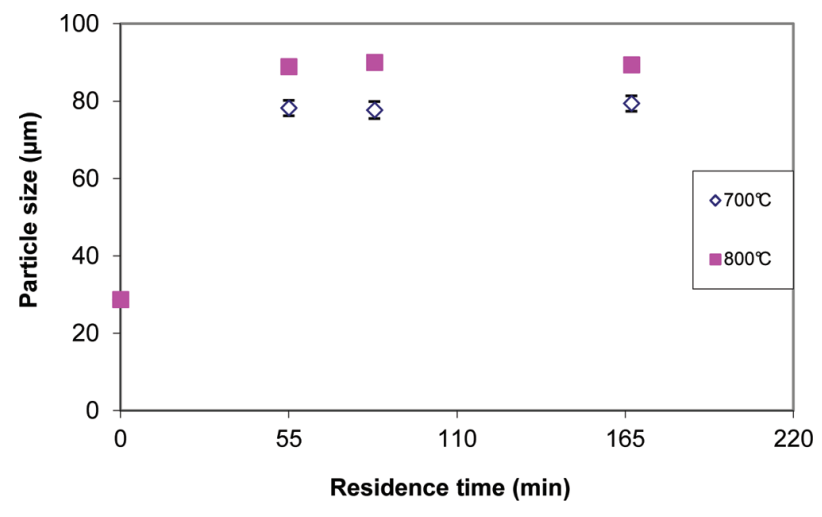

Figure 9. Particle size growth during calcination.

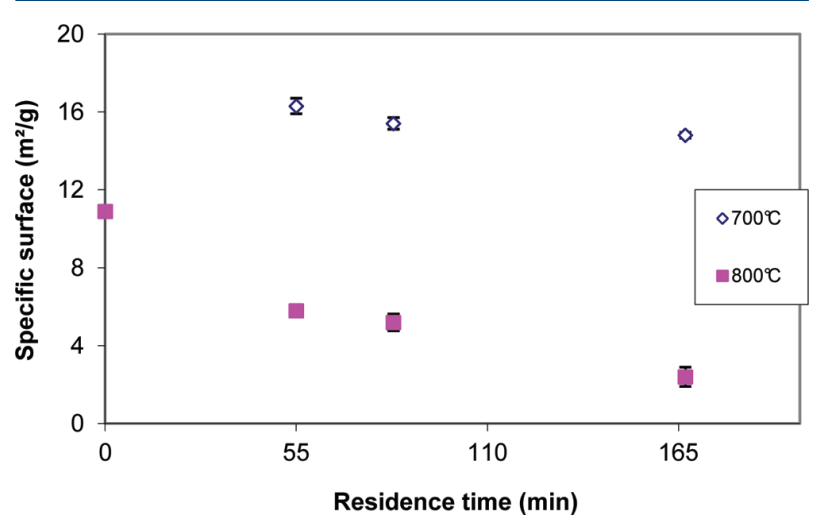

Figure 10. Specific surface versus residence time during calcination.

Table 5. Results of Leaching Tests for Sediments SV and SD Calcined in a Rotary Kiln

\begin{tabular}{|c|c|c|c|c|c|}
\hline & \multirow[b]{2}{*}{$\mathrm{pH}$} & \multicolumn{4}{|c|}{ Amount Leached $\left(\mathrm{mg} \mathrm{L}^{-1}\right)$} \\
\hline & & $\mathrm{Zn}$ & $\mathrm{Pb}$ & $\mathrm{Cd}$ & As \\
\hline \multicolumn{6}{|c|}{ (a) Results of Leaching Tests for Sediment SV } \\
\hline raw & 7.4 & 2.6 & 2.2 & 0.023 & 0.004 \\
\hline phosphated & 7.2 & 0.213 & 0.016 & 0.016 & 0.068 \\
\hline $600{ }^{\circ} \mathrm{C}$ & 9.2 & 0.024 & 0.019 & 0.004 & 0.064 \\
\hline $700{ }^{\circ} \mathrm{C}$ & 9.4 & 0.028 & 0.02 & 0.004 & 0.062 \\
\hline $800{ }^{\circ} \mathrm{C}$ & 10.4 & 0.021 & 0.019 & 0.004 & 0.076 \\
\hline $\begin{array}{l}\text { limit values for landfilling for } \\
\text { waste }\end{array}$ & & 4 & 0.5 & 0.04 & 0.5 \\
\hline \multicolumn{6}{|c|}{ (b) Results of Leaching Tests for Sediment SD } \\
\hline raw & 7.6 & 3.4 & 2.9 & 0.049 & 0.007 \\
\hline phosphated & 7.9 & 0.323 & 0.0112 & 0.032 & 0.232 \\
\hline $600{ }^{\circ} \mathrm{C}$ & 10.2 & 0.756 & 0.02 & 0.003 & 0.067 \\
\hline $700{ }^{\circ} \mathrm{C}$ & 10.3 & 0.845 & 0.023 & 0.003 & 0.078 \\
\hline $800{ }^{\circ} \mathrm{C}$ & 10.8 & 0.521 & 0.018 & 0.003 & 0.071 \\
\hline $\begin{array}{l}\text { limit values for landfilling for } \\
\text { waste }\end{array}$ & & 4 & 0.5 & 0.04 & 0.5 \\
\hline
\end{tabular}

showed that the concentrations of heavy metals analyzed after calcination in a rotary kiln are well below the limit values for landfilling for waste. The quantities of heavy metals from calcined sediments are very low, compared to those of the phosphated sediments. This allows us to assert that the calcination procedure improves the stability and immobilization of heavy metals.

Examples of the Incorporation of NOVOSOL-Treated Dredged Sediments in Civil Engineering. NOVOSOL- treated sediments have been used as alternative materials for the manufacture of brick on an industrial scale. For this study, treated sediment were introduced into the brick-manufacturing process as a replacement of sand 1 (quartz sand) with a substitution ratio of $15 \%$. Approximately 15000 of sedimentamended perforated bricks $(6 \mathrm{~cm} \times 22 \mathrm{~cm} \times 22 \mathrm{~cm})$ were produced. The produced bricks were subjected to several qualification tests. The results obtained have demonstrated that sediment-amended bricks meet the "clay brick" specifications and environmental requirements given by the existing standards. ${ }^{17,18}$

In other applications, NOVOSOL-treated sediments have been used as substitute materials in the composition of sand cement mortar. Three mortars for which a given sand volume was replaced by the same sediment volume $(33 \%, 66 \%$, and $100 \%)$ were designed. The study proved the practical feasibility of introducing treated sediments in cement-based materials. ${ }^{19}$

\section{CONCLUSION}

The specific surface area and particle size characteristics of two dredged sediments were studied, with regard to two main parameters (namely, temperature and residence time). Generally, it was found that the specific surface area of both sediments decreases with increasing temperature. The surface reduction was found to be due to a reduction in porosity that resulted from the degradation of organic matter and the evaporation of $\mathrm{CO}_{2}$ and water, followed by thermal sintering. The size measurements and environmental scanning electron microscopy (ESEM) images taken on samples calcined at temperatures above $700{ }^{\circ} \mathrm{C}$ clearly demonstrate particle growth. By varying the residence time, results from $700{ }^{\circ} \mathrm{C}$ showed that just $55 \mathrm{~min}$ of calcination is needed to degrade the organic matter. It was noted that the specific surface area decreases when the residence time increases. It was observed that, at 700 and $800{ }^{\circ} \mathrm{C}$, the specific surface area decreases as the dwell time increases. The results obtained for various characterization techniques confirmed the sintering phenomenon. It is important to notice that good agreement was observed between the results obtained at laboratory scale and pilot scale. It appears that the physical characteristics of the sediments could be controlled by adjusting the temperature and residence time. This opens up very promising perspectives with regard to the recovery and reuse of treated dredged sediment in civil engineering, including the manufacturing of bricks and mortar, and of road materials.

\section{AUTHOR INFORMATION}

\section{Corresponding Author}

*E-mail: jocelyn.ramaroson@mines-albi.fr.

Notes

The authors declare no competing financial interest.

\section{ACKNOWLEDGMENTS}

The authors wish to express their gratitude to Solvay SA for providing samples and for the financial support to this work. The expertise from Prof. P. Sharrock is also acknowledged.

\section{REFERENCES}

(1) Miller, J. R.; Hadson-Edwards, K. A. Heavy metal contamination of water, soil and sediment produced within riverine communities. Sci. Total Environ. 2004, 30, 189-209. 
(2) Lei, L.; Khodadoust, A. P.; Suidan, M. T.; Tabak, H. H. Biodegradation of sediment-bound $\mathrm{PAHs}$ in field-contaminated sediment. Water Res. 2005, 39, 349-361.

(3) Rausa, R; Mascolo, G. Thermal treatment of sediments as function of temperature and reacting atmosphere. J. Anal. Appl. Pyrolysis 1999, 49, 425-445.

(4) Lee, I.-H; Wang, Y-J; Chern, J.-M. Extraction kinetics of heavy metal-containing sludge. J. Hazard. Mater. 2005, 123, 112-119.

(5) Marot, F. Characterization and treatment of the Sediments of Dredging Containing of the Metal Pollutants. BRGM: Paris, 1998; $\mathrm{p} 330$.

(6) Derie, R.; Depelsenaire, G.; Nzihou, A. Procédé d'inertage de boue/Sludge treatment method, SOLVAY, FR2845983 and WO2004035490, April 23, 2004

(7) Mulligan, C.; Yong, R.; Gibbs, B. An evaluation of technologies for the heavy metal remediation of dredged sediments. J. Hazard. Mater. 2001, 85, 145-163.

(8) Kribi, S. Decomposition of the organic matter and stabilization of heavy metals in the dredged sediments, Ph.D. Thesis, INSA: Lyon, France, 2005; p 220.

(9) AFNOR Standard; Quality of grounds. 1999; p 250.

(10) Mellmann, J. The transverse motion of solids in rotating cylinders-Forms of motion and transition behaviour. Powder Technol. 2001, 118, 251-270.

(11) Sullivan, J. D.; Maier, C. G.; Ralston, O. C. Passage of solids particles through rotary cylindrical kilns. U.S. Bur. Mines, Tech. Pap. $1927,384,1-42$.

(12) United States Environmental Protection Agency (USEPA). Identification and Listing of Hazardous Waste, The Code of Federal Regulations; Office of the Federal Register, National Archives and Records Administration, Washington, DC, 1999; Vol. 40, pp 1-261.

(13) German, R. M. Surface area reduction kinetics during intermediate stage sintering. J. Am. Ceram. Soc. 1978, 61, 272-274.

(14) German, R. M.; Munir, Z. A. Surface area reduction during isothermal sintering. J. Am. Ceram. Soc. 1976, 59, 379-383.

(15) Ramaroson, J.; Dirion, J-L; Nzihou, A.; Sharrock, P.; Depelsenaire, G. Calcination of dredged sediments: Investigation of the behaviour heavy metal and the organic compounds. High Temp. Mater. Process. 2008, 27, 227-336.

(16) Michel, F. Les granulats. Union des producteurs de granulats, 2006; p 17.

(17) Samara, M.; Lafhaj, Z.; Chapiseau, C. Valorization of stabilized river sediments in fired clay bricks: Factory scale experiment. J. Hazard. Mater. 2009, 163, 701-710.

(18) Lafhaj, Z.; Samara, M.; Agostini, F.; Boucard, L.; Skoczylas, F.; Depelsenaire, G. Polluted river sediments from the North region of France: treatment with Novosol process and valorization in clay brick. Construct. Build. Mater. 2007, 22, 755-762.

(19) Agostini, F.; Skoczylas, F.; Lafhaj, Z. About a possible valorization in cementitous materials of polluted sediments after treatment. Cem. Concr. Compos. 2007, 29, 270-278.

(20) Scordia, P. Caractérisation et valorisation des sédiments fluviaux pollués et traits dans les matériaux routiers, Thèse de doctorat: Ecole Centrale de Lille, Lille, France, 2008; p 189. 